\title{
Historical Examination of Agent Concept
}

\author{
Samson A. Liberman
}

\begin{abstract}
Throughout the development of thought from the classical forms of philosophizing to the present, the understanding of the subject also changes. The transition from the Hegelian substance subject to the individual transcending subject is carried out, and then the "death of the subject" in all its forms (God, social, author, etc.). Such a fundamentally new understanding, the interpretation of human consciousness and being, is primarily associated with the emergence of a fundamentally new way of this consciousness functioning. This work is devoted to the consideration of this determining connection between the forms of theoretical problematization of a subject in philosophical thought and changes in social structure. They may consider the allocation of three main historical stages of the subject problematization and the corresponding forms of social as the main results. In the era of the New Age, there is understanding of a subject as a participant in history, who is the product of history and the creator. At the turn of the nineteenth and twentieth centuries, this understanding is being transformed and refined. Now they deny subject rootedness in the transcendental field on the one hand, and this rootedness should seek and achieve on the other hand. The motive for a breakthrough towards the absolute and overcoming one's own "queerness" becomes the main one. In the second half of XXth century, they form a special view of the subject - he is now problematized as absent.
\end{abstract}

Keywords: social subject, subject death, mass person, transcending, ideology.

\section{INTRODUCTION}

Society becomes the subject of philosophy (that is, it becomes a special independent type of reality, social or historical reality with its own characteristics and regularities) when history and society become a problem for a person. Society ceases to be transparent and obvious, history ceases to be a parable, a fairy tale. History reveals itself precisely where the problem of history arises, where history ceases to be ours.

Suddenly, historians "discover" that the ancient Greek thought completely differently than I think today. He thought so differently that reasonable doubts arise: "did he think at all?" "It is revealed" that he does not understand and cannot fundamentally understand some simple and obvious things for us. And I also do not understand, and fundamentally unable to understand things, completely obvious to the Greek. Man and society find themselves face to face with themselves and do not recognize themselves.

What is the reason? Obviously, one of the reasons is the acceleration of the passage of time. Thus, the concept of age, and growing up appears. A child is perceived now not as an underdeveloped adult, but as a stage in a person's development, a specific and unique stage. Changes occurring in a person and with a person are accelerated, it becomes easier to track and see them. It is also interesting why a person

Revised Manuscript Received on November 08, 2019

* Correspondence Author

Samson A. Liberman, Kazan Federal University suddenly began to peer and notice these changes, as it is obvious that earlier certain changes also took place with a person, he also grew up and developed. So why did it become noticeable at the beginning of the New Time?

\section{METHODS}

According to Sogomonov and Uvarov, "Europe, as it was found in the 16th century, was a complex and fragmented society ... Man was simultaneously included in various holistic communities, which ... were in extremely complicated relations of subordination, rivalry, competition, contradiction ... the factor of balance maintaining inside this solidarity, as well as between them, was the metaphor for a single mystical body" [Sogomonov, 205]. These "holistic communities" continue to multiply at an extraordinary pace, and soon the contradictions between them are not able to contain a single metaphor.

After the destruction of the "single mystical body," everyone is forced to embed himself in this body, develop and build up the relationship for himself. That is why a person suddenly begins to peer into himself, to separate the old self from the present, to build and conceive the future of himself. Uvarov and Sogomonov call this the birth of the "social" [Sogomonov]. An individual attitude arises about what I am, what is the world, and how I interact with this world. There is a need for a personal attitude to existing social relations, the structure of a social subject arises.

The philosophy of history, the first form of social philosophy, appears precisely at the beginning of the New Age. It could never have occurred to the early medieval scholastic that Aristotle did not put in his works what he, the scholastic, was reading from there. As well as Aristotle, who criticized the "pre-Socratics", who could not have imagined that it was fundamentally unthinkable for them to separate the substrate material from the reason for its movement, that their matter was fundamentally "self-moving".

This kind of historicism is a necessary form of social self-awareness of the modern era. To sell himself as a social subject, each person is forced to build "his story", thereby including himself in "history in general", assigning it, and, oddly enough, giving rise to this story in general. History is the result of my work, and I am the product of history. Thus, in order to make the Cartesian subject, as well as the free personality of the artist, as well as the Hegelian idea of the "substance-subject" appear this condition is necessary. A real person must "fall out" of the "single mystical body" in order to be forced to create artificial social structures to replace the lost "natural" ones, forced to relate to himself and the existing state of affairs, to develop a certain attitude.

The birth of a classical social subject is, first of all, the objectification of oneself and the environment. The appearance of such a worldview is the consequence of historical sense, forced reflection, 
exfoliation or stratification of oneself "before" and "after". A person is forced to act, to change the existing state of affairs and himself, he is forced to be a subject. However, at the turn of the XIX-XX centuries, changes are taking place in the structure of a social subject.

\section{RESULTS AND DISCUSSION}

However, at the turn of the XIX-XX centuries, the transformation of the theoretical concept of a subject. The main motive, in our opinion, is the motive of effort and formation. The motive of transcendence to the position of the absolute. And such a transformation is necessarily accompanied by the changes society functioning real ways.

Why should an action be an effort for me, and for me precisely as a free subject? Is freedom not the opposite of effort when I am free to do only that which is done easily and naturally? Is freedom not freedom from coercion, including self-coercion, in particular? It turns out that it is not.

Freedom is always the effort to be free. Hegel writes the following about this: “... freedom itself contains the infinite need to be aware of oneself and thereby become real, therefore it is knowledge of oneself by its concept, it is the goal for itself ..." [Hegel, 72]. Freedom is not something that has happened once, and thus has come true. Freedom is something that needs to be done regularly, "a thinking person is simply obliged to do this from time to time." That same Munchausen's daily feat, and the feat always involves some effort.

Freedom is always a choice, it will always be determined by necessity, only it does not become easier from this. On the contrary, the acceptance of necessity presupposes a certain amount of tragedy and drama. Moral choice is always a conflict, and a dramatic conflict in the sense of a dramatic work conflict. There is a point of view according to which the subject appears first in Greek tragedy [Tereshchenko, 171]. Greek tragedy occurs during the collapse of the Greek polis (as does mathematics with philosophy). However, the social subject is a modern form of social relations, and the extension of this principle to the Greek crisis of the policy is attractive, but not justified.

Despite the fact that in some form this logic of effort is also present in the classics, it becomes the leading motive, the motive of personal breakthrough and transcending in non-classical philosophy. If the appearance of the classical subject concept was associated with the appearance of a real available way of subjective social relations, then the radicalization and strengthening of this concept is associated with the emergence of mass consciousness and mass people. We will associate the emergence of a mass person with the appearance of such a phenomenon as mass production [Ameen, et al 2018; Peres, et al 2018; Kor, et al 2019; Nurgaliyeva, et al 2018].

A relatively small number of people, having mastered the technology of mass replication creation, copies of samples, proved to be able to provide the life of a much larger number of people by their work than before. Consequently, a whole mass of people became free. The thing is about the people who were not engaged in the direct production of what they live, in labor and in objective transformative activity. However, we should understand consumption as an equal part of social production, consumption can also be interpreted as transformative activity: it is necessary to distribute goods to consume, to do some work on it. It turns out that the point is not that a person is not directly involved in production.

The point is the specifics of mass production, the production of copies according to samples. In order to consume copies, I do not need to distribute a copy every time, it is enough for me to master the technology of consumption. Thus, we have not distributive activity, but the implementation of technology, which does not imply the emergence of individual consciousness in its classic, modern version. Mass production of copies involves only mass consciousness, consuming copies, which in its essence is the reproduction of the original consciousness, the consciousness-copy. A copy has no history, and a copy-consciousness cannot have a historical feeling, since there is no need for reflection and self-awareness. Under the conditions of mass production and, accordingly, mass consumption, that modern historical subject that generates history and generates itself from history does not work. And that is precisely why the problem of the subject unfolds in a new way in philosophy at this time.

Non-classical philosophers cannot help but feel such changes in the structure of consciousness. Moreover, these changes take place not only and not so much "outside the window" as within the philosophers themselves. That is why Nietzsche is so concerned about getting rid of "human, too human" [Nietzsche], Marx - about building a classless non-ideological society [Marx], and Freud - about curing neurosis [Freud]. Philosophy at the turn of the XIX-XXth century suddenly found that it is inaccessible now to the position of the absolute, that it is not at the point of extra broadness. A modern philosopher cannot, like Descartes, reach the first evidence with the effort of the mind, since he is within the framework of a certain historicity, ideology, commitment, neurosis, etc.

A man is not a subject by birthright anymore. On the contrary, he is only a mass person by birth right in his era, and it is necessary to make certain efforts for a breakthrough to comprehension of the truth, to philosophizing, to his own subjectivity, to his true being. The efforts to create history, which means overcoming one's own past, denying given reality, identity. The only genuine being is the essence of human being, the being that denies its identity, pulls itself by the hair, like Munchausen, from a swamp, literally hanging by a thread.

It seems to us that this motive permeates not only the constructions of the authors already mentioned. We can find it in one form or another both in the "philosophy of Life" and existentialism, and in neo-Marxism and psychoanalysis; both in neo-Kantianism and in the philosophy of language. This uniformity of non-classical philosophers is conditioned by the commonality of the social situation in which they are placed, the situation of the transcendent withering away. A marker of this situation is an unprecedented ideological surge. The motive for the efforts of history is also manifested in the appearance of the very fact of mass (not class!) ideology.

\section{CONCLUSIONS}

The final transition to modern philosophy, to the philosophy of contemporaneity is associated with the proclamation of the final "death" of the social subject, the principle of subjectivity and social as such. 
In the era of non-classical philosophy, the era of radical localization and crystallization of the transcendent in the individual consciousness, corresponds to the appearance of a total state. This becomes possible just because ideology takes the place of classical metaphysics, the history of man or the superman takes the place of the History of the Spirit. If the first was transcendental, albeit incarnate, that is, it moved from heaven to earth, then the second passes through everyone's heart and then soars up to new horizons and a brighter future, to a new universal. "From the heart to the sun", the well-known wording - the message of the fascist greeting is a very accurate description of any mass ideology. The thinkers of postmodernism and post-nonclassics reveal this hidden ideology. However, the transition from ideological consciousness to truly mass consciousness, as Baudrillard, for example, interprets it, could not be determined by the conscious decision of theoretical thinkers. Postmodernists do not kill the transcendental; they only record its death.

The death of the transcendent and the transition from the neoclassical at the turn of the XIX-XXth century to the philosophy of modernity is driven by objective historical processes. As we said, mass consciousness appears along with mass production and consumption. Copy-consciousness is not capable of goal-setting. This skill or organ, if not absent as such, is atrophied at least. According to M.K. Mamardashvili, E.Yu. Soloviev and V.S. Shvyrev in the work "Classics and Modernity": "In place of the slow, spontaneous ripening of myths ... modern capitalism has set up a kind of rational fabrication of mythologies. The process of generalization, figuratively-conceptual design of fetishistic ideas ... used to take centuries. Today it is artificially accelerated, forced ... there is a special "industry of consciousness" " [Mamardashvili, 41].

If in the first half of the 20th century this industry is still trying to replace the lost transcendental ideology, then by the middle of the century this possibility is exhausting itself. Totalitarianism is being replaced by neototalitarianism, as Herbert Marcuse describes it: "Technological progress ... creates life forms (and authorities) that ... bring together opposing forces ... modern society has the ability to restrain qualitative social changes ... the general approval of the National Goal, ... the conspiracy between Business and Labor within the framework of a strong state, it testifies to the merging of opposites ... The all-conquering interest in maintaining and improving the institutional status quo unites the former antagonists" [Marcuse, 9-10].

J. Baudrillard, who is actually known for the formula "death of the social" [Baudrillard, 1983], calls this process "neutralization". All social tensions, all contradictions are neutralized in the name of the "status quo" preservation: "the historical goal has been removed from our lives by this kind of gigantic neutralization, called peaceful coexistence on a global scale, and pacified monotony on a daily scale ..." [Baudrillard, 1994, 62]. The era of modernity and history is degenerating into endless modernization and modernity. Moreover, according to Baudrillard, the previous era of a surge in History refers to the interval between the two world wars, provoked by the same logic of neutralization and is a reaction to it, "the agony of powerful referents, the agony of the real and rational" [Baudrillard, 1994, 63]: "Fascism is resistance to this, resistance to limitless, irrational, dementia ... it would not attract this mass energy if it were not resistance

to something even worse. Its cruelty, its horror correlates with even greater horror, which comes from a mixture of the real and the rational" [Baudrillard, 1994, 65].

What happens to the subject in this era of total "neutralization"? As we already said, the preceding era tried to recreate the lost referent of subjectivity, to instill it in the masses from the outside, but now when these efforts are abandoned, the individual subject is finally dissolved in the mass. The new ideology, positioning itself as an a-ideology, or, as Baudrillard calls it, the ideology of peaceful coexistence, preaching tolerance and neutralizing all opposites and contradiction in itself, neutralizes the subject-object relationship. If in the previous epochs we highlighted, we could talk about direct actions of subjects or about their manipulation, then all these boundaries are erased in the era of the Present. If the basis of relations in the classical era, according to Foucault, is the relation of supervision and panopticon, now it is impossible to separate the one who exercises supervision from the one over whom it is carried out.

Following Baudrillard, an example of such a phenomenon can be considered a "reality show." From now on, the subject is dissolved and decentralized, it is impossible to say who oversees whom: "This is the next stage of social relations ... which is no longer a stage of persuasion, but a stage of dissuasion: "YOU are the latest news, you are a social one, you are an event, you have something to do with it, the word to you" etc." [Baudrillard, 1994, 45].

Such is the Present, in which and with which the postmodern thinkers work, and there is no place for the classical subject and the classical social here as a relation to the social relation, since now neither an individual relation to anything nor real social relations are possible. This is the situation of the social subject crisis. The situation of mass society leads to various kinds of subject death in the framework of the theoretical space.

\section{SUMMARY}

Thus, the known transformations in the theoretical field regarding the understanding of the subject are explained not only by the change and development of theoretical tools, but, first of all, by the change in the social situation itself and the development of society functioning ways - from the collapse of a "single mystical body" at the turn of the Middle Ages and the New Time, through ideologization at the turn of the XIX-XXth centuries to the mass society of the second half of the XXth century.

\section{ACKNOWLEDGEMENTS}

The work is performed according to the Russian Government Program of Competitive Growth of Kazan Federal University.

\section{REFERENCES}

1. Sogomonov A.Yu., Uvarov P.Yu. The discovery of social (paradox of the XVIth century). // Odyssey. M.: Nauka, 2001.

2. Hegel, G.W.F. (1975). Lectures on the philosophy of world history. Introduction, reason in history. (translated from the German edition of Johannes Hoffmeister from Hegel papers assembled by H. B. Nisbet) New York, NY: Cambridge University Press 
3. Tereshchenko N.A. Social philosophy after the "death of the social." Kazan: Kazan Univ., 2011. - 368 p.

4. Nietzsche, F. (2004) Human, All Too Human. Penguin Classics. Transl. Marion Faber. Penguin Books

5. Marx, K.; Engels, F. (2004) Manifesto of the Communist Party. Marxists Internet Archive. Retrieved on 14 March 2015

6. Freud, S. (1949) The Ego and the Id. The Hogarth Press Ltd. London.

7. Mamardashvili M.K. Classics and Modernity: Two Eras in the Development of Bourgeois Philosophy / M.K. Mamardashvili, E.Yu. Soloviev, V.S. Shvyrev. M.: 1972. - 50 p.

8. Marcuse, Herbert (1991) One-dimensional Man: studies in ideology of advanced industrial society. London: Routledge

9. Baudrillard, J. (1983). In the Shadow of the Silent Majorities. Semiotext $(\mathrm{e})$

10. Baudrillard, J. (1994). Simulacra and simulation. University of Michigan press.

11. Ameen, A. M., Ahmed, M. F., \& Hafez, M. A. A. (2018). The Impact of Management Accounting and How It Can Be Implemented into the Organizational Culture. Dutch Journal of Finance and Management, 2(1), 02.

12. Peres, P., Moreira, F., \& Mesquita, A. (2018). Are Really Technologies at the Fingers of Teachers? Results from a Higher Education Institution in Portugal. Journal of Information Systems Engineering \& Management, 3(1), 08

13. Kor, L., Teoh, S., Binti Mohamed, S. S. E., \& Singh, P. (2019). Learning to Make Sense of Fractions: Some Insights from the Malaysian Primary 4 Pupils. International Electronic Journal of Mathematics Education, 14(1), 169-182 https://doi.org/10.29333/iejme/3985

14. Nurgaliyeva, S., Zeynolla, S., Tulenova, U., Zulkarnayeva, Z., \& Yespolova, G. (2018). Features of institutional autonomy of the Kazakhstan's universities. Opción, 34(85-2), 302-336 